\title{
INDIVIDUAL RIGHTS AND SOCIAL WELFARE: THE EMERGING LEGAL ISSUES
}

\author{
CHARLES A. REICH*
}

THE time has come for lawyers to take a major interest in social welfare, and for the welfare profession to concern itself with the rapidly growing relevance of law. Although welfare has always existed within a structure of law, until recently there has been little recognition or study of the basic legal issues underlying decisions affecting recipients of public assistance and other welfare beneficiaries. These issues will lie quiet no longer; they urgently demand our attention.

The New Deal undertook a far-reaching experiment in social welfare, with the rapid enactment of new legislation in the fields of social security, unemployment compensation, public housing, and other forms of public aid. Since that time the experiment has been accepted as a fundamental and permanent aspect of our society. But although thirty years have passed, and a vast amount of experience has accumulated, there has been little in the way of critical examination of the legal issues in these welfare statutes - least of all by those who support the general principles of social welfare, and least of all with respect 10 issues concerning the substantive and procedural rights of individual beneficiaries. It is not surprising, then, that the legal status of these individuals' rights requires critical reexamination.

The law of social welfare grew up on the theory that welfare is a "gratuity" furnished by the state, and thus may be made subject to whatever conditions the state sees fit to impose. A corollary legal theory holds that since all forms of welfare represent the expenditure of public funds, the public may properly interest itself in these funds even after they have reached the hands of beneficiaries. With these justifications at hand, recipients have been subjected to many forms of procedure and control not imposed on other citizens. No one will deny that fair and reasonable eligibility standards and effective protection against fraud are necessary when benefits are handed out. But the poor are all too easily regulated. ${ }^{1}$ They are an irresistible temptation to

*Professor of Law, Yale University. The author wishes to thank Mrs. Elizabeth Wickenden for invaluable help both on the general philosophy of this article and on its discussion of specific issues; also Brian Glick and David Pittinsky for their assistance on legal research.

1. "Paradoxical though it may seem, the most serious threat to freedom in our programs of public services and public benefits is to the freedom of the recipient. The original Agricultural Adjustment Act was once described, rather harshly, as government by bribery. The power of the purse is great; it is sometimes possible, by paying people to do things or not to do them, to control their actions as effectively as by threatening to send them to jail. It behooves us to be constantly on our guard lest, out of zeal to better people's lot, we impose on them patterns of behavior in matters in which, under our scheme of things, government ought not to meddle."

Willcox, Patterns of Social Legislation: Reflections on the Welfare State, 6 J. of Pub. L. 3, 7 (1957). 
moralists, who want not only to assist but to "improve" by imposing virtue. They are subject to social workers' urges to prescribe "what is best." And they are necessarily caught up in the workings of large organizations which by their nature are rigid and dehumanizing.

The Social Security Act represented a departure from this general welfare philosophy. The framers of the Act had a clear concept concerning the "right" to public assistance, and provided devices to protect these rights. Thus, in the program for aid to families with needy children, the Act requires that states afford an opportunity for a fair hearing to any individual whose claim is denied or not acted upon with reasonable promptness, provide safeguards which restrict the use or disclosure of information concerning recipients, and cnsure that all individuals wishing to make application for aid have opportunity to do so. ${ }^{3}$ Despite these and other statutory safeguards, problems have grown up with respect to federal as well as state programs. In part, these are the outgrowth of difficulties in administration.

Welfare is surrounded by the processes of administrative procedure. The procedures of the New Deal regulatory agencies were looked upon with high hopes by the reformers of thirty years ago, who sought fair and simplified alternatives to the cumbersome methods of the courts. But the administrative process has developed its own abuses and oppressiveness. These abuses are harmful whatever the work of an agency, but their impact on people as individuals is perhaps greatest in the welfare field. The clients of many government agencies are large organizations; those who deal with the Federal Communications Commission or the Civil Aeronautics Board are usually well able to protect themselves. Welfare clients are often ignorant of their rights, lack adequate representation by counsel, and lack the resources to fight a large public agency. If even our biggest corporations sometimes find government (no matter how well-meaning) to be arbitrary and oppressive, we may expect to find that the welfare beneficiary often suffers far more from heavy handed governmental regulation. There is mounting evidence to confirm this expectation.

\section{A Sampling of Issues}

Although there has as yet been no systematic effort to uncover legal issues involving welfare beneficiaries, some problems have, particularly in recent months, forced themselves upon persons working in the social welfare field. ${ }^{4}$ These problems arise in many different welfare programs, federal and state, including aid to families with needy children, other forms of public assistance,

2. See Schorr, The Trend to Rx, Social Work, January, 1962.

3. 42 U.S.C. $\$ 602$ (1962).

4. See generally Wickenden \& Bell, Public Welfare - Time for a Change (1961) ; U.S. Dept. of Health, Education and Welfare, The Extension of Legal Services To THE Poor (1964); Wickenden, Memorandum: Poverty and the Law, The Constitutional Rights of Assistance Recipients, March 25, 1965; U.S. Advisory Commission on Intergovernmental Relations, Statutory and Administrative Controls Associated With Federal Grants for Public Assistance (1964). 
unemployment insurance, job retraining, public housing, and the new Economic Opportunity Act. They are most readily sorted out, however, in terms of the impact on the recipient or his family.

Morals. Some welfare regulation attempts to impose a standard of moral behavior on beneficiaries. Louisiana cut off aid to needy children in all cases where the mother gave birth to an illegitimate child after going on the relief rolls, except where she could prove that she had subsequently "ceased such illicit relationships." Twenty-three thousand children, a large proportion of them Negro, were removed from assistance before the Secretary of Health, Education and Welfare ruled Louisiana's plan invalid under the Department's own standards. ${ }^{5}$ In other states mothers of illegitimate children may be dissuaded from applying for assistance by threats of neglect proceedings leading to loss of custody of the child or children. ${ }^{6}$ Sometimes mothers who, while receiving assistance for their children, give birth to an illegitimate child are subjected to the charge that the latest pregnancy constitutes "neglect" of the previous children. ${ }^{7}$ In California, if a mother receiving aid to dependent children uses any portion of the grant to support a man "assuming the role of spouse" to whom she is not married she may be charged with the crime of misusing the grant, ${ }^{8}$ despite the fact that such grants may be used to support a lawful husband or other caretaker-relatives. She is also in danger of being charged with grand theft if she receives assistance and fails to disclose that she is living with a man deemed capable of rendering financial support, although he may be far less than a full time member of the family ; thus illicit relationships are hazardous. In the District of Columbia, the courts were faced with the question whether the mother of nine must be denied aid because her estranged legitimate husband visited her too frequently. ${ }^{10}$ In no other area of entitlement, such as social security or veterans' benefits, are there similar pressures to impose a moral code.

Privacy. In order to administer public welfare funds, investigation of eligibility and extent of need are both normal and necessary. Merchants may be asked for information, financial data is checked, the whereabouts of relatives

5. Memorandum for The Commissioner of Social Security from Secretary Flemming, January 16, 1961. See Wickenden, The Indigent and Welfare Administration, in U.S. Dept. of Health, Education and Welfare, Conference Proceedings: The Extension of Legal Services to the Poor, 42 (1964).

6. Wickenden, Memorandum: Poverty and the Law, The Constitutional Rights of Assistance Recipients (March 25, 1965) p. 6.

7. Ibid. at 5 .

8. See Opinion of Attorney General of California 64/63, 44. A.G.O. 155 ; Calif. WelfaRe AND InStitutions Code § 1508, 1575.

9. People v. Shirley, 360 P.2d 33, 55 Cal. App. 2d 521 (1961). See Calif. Welfare \& Institutions CODE $\S 508.42$ U.S.C. $\S 605$ sanctions the use of state criminal penalties to punish relatives who do not use aid for the benefit of the children on whose behalf it is received.

10. Simmons v. Simmons, Civil No. D 2545-61, D.C. Ct. of Gen. Sessions, Domestic Relations Branch, June 12, 1964 ; See Washington Post, Nov. 10, 1964, p. C 1. 
sought. ${ }^{11}$ Investigation is, however, inevitably an invasion of privacy, and all the more so if steps are not taken to keep the findings confidential. ${ }^{12}$ One specific invasion of privacy that seems both illegal and unwarranted is the widespread practice of conducting "midnight raids" on homes receiving aid to dependent children, to see if there is a "man in the house" who is or should be contributing to the family's support. ${ }^{13}$ Investigators may burst in, frighten the children, and threaten the mother with loss of assistance. Several states have halted this practice, but elsewhere it continues unchecked. ${ }^{14}$

Responsibility. Welfare laws sometimes seek to impose duties of financial responsibility for relatives beyond those required by the general law. ${ }^{15}$ The concept of relatives' responsibility is a survival from the Elizabethan poor laws, which attempted to compel relatives to support indigent members of their families. ${ }^{16}$ Controversy over such requirements is active today; California's highest court recently held unconstitutional the requirement that children be compelled to support the care of aged parents in mental institutions. ${ }^{17}$ Under aid to families with dependent children programs in many states, a "man in the house," although not married, may be presumed to be responsible for contributing to the support of the woman's children.

Residence. Another survival of the Elizabethan poor laws is the doctrine that public assistance is basically a matter of local concern, and the corollary that only residents of the states are entitled to be assisted. ${ }^{18}$ Many states have statutes denying assistance to persons who do not qualify as residents, and making it difficult to become a "resident."19 Many laws now on the books are designed to hinder the migration of indigents. Some of these laws have been held unconstitutional, ${ }^{20}$ but New York has a law disqualifying one who comes to the state for the purpose of obtaining welfare, ${ }^{21}$ South Dakota has a law making

11. E.g., N.Y. Social Welfare Law $\S 132,143$ (a) ; Calif. Welfare \& Institutions CODE $§ 1523,1572$.

12. See, e.g., Cal. Welfare \& Institutions Code $\S 1552.6$.

$1 \rightarrow$ Reich, Midnight Welfare Searches and the Social Security Act, 72 Yale L.J. 1347 (1963) ; U.S. Comptroller General, Report on the Adequacy of the Nationwide Review of Eligibility in the Aid to Families with Dependent Children Program Welfare Administration, Department of Health, Education, and Welfare JanuaryJULY 1963, 18-22.

14. See, e.g., Baltimore Sun, January 19, 1964, p. 1, 20 ; N.Y. Times, August 23, 1964, p. 66; Americn Civil Liberties Weekly Bulletin No. 2209, (1964) p. 1.

15. Calif. Welfare \& Institutions Code $\S 2181,2224,2576,2881$; N.Y. Social Welfare Law § 101 . See generally Mandelker, General Assistance in the United States, Ch. III 1955 (unpublished thesis in Yale Law School Library).

16. ten Broek, California's Dual System of Family Law: Its Origin, Development and Present Status: I, 16 Stan. L. Rev. 257, 283 (1964).

17. Department of Mental Hygiene v. Kirchner, 60 C.2d 716, 36 Cal. Rptr. 488, 388 P.2d 720 (1964), vacated and remanded, 380 U.S. 194 (1965).

18. tenBroek, supra note 16 , at 262-65 (1964).

19. N.Y. Social Welfare Law $\S 117-21,149$ (McKinney Supp. 1964) ; N.Y. Social WELFARE LAW $\S 148$.

20. Edwards v. California, 314 U.S. 160 (1941).

21. N.Y. Social Welfare Law § 139-a (Supp. 1964). 
it virtually impossible for migrants to receive general public assistance, ${ }^{22}$ and many states have laws authorizing the "removal" of indigents back to their state of origin. ${ }^{23}$ The removal statutes seem plainly unconstitutional, but remain on the books and are indirectly enforced by the threatened withdrawal of assistance. In one New York case, assistance was denied because the authorities deemed it "socially valid" for the applicant to return to her family in a southern state from which she had departed. ${ }^{24}$ Settlement and removal laws, and more recent reciprocal agreements concerning the settlement of children, may also hinder the interstate placement of children in foster homes or for adoption, making it difficult for a court or agency to send a child to a family in a state which demands assurances that the child will not become a public charge. ${ }^{25}$

Employment. Whether a welfare recipient must work to obtain assistance, and what work he may be compelled to do, have also been issues since the days of the Elizabethan poor laws. ${ }^{26}$ "Work relief" still exists. ${ }^{27}$ Recently several men in upstate New York challenged the power of St. Lawrence County to compel them, subject to criminal penalties, to work cutting brush in deep snow. ${ }^{28}$ Fathers refusing work relief have been criminally prosecuted for nonsupport. An even more difficult problem concerning employment arises in connection with vocational retraining programs which are part of some state schemes for unemployment compensation, ${ }^{29}$ and an important part of the new federal poverty programs. ${ }^{30}$ Here an individual is put under pressure to

22. South Dakota Code $\S 50.0102(6)$.

23. See generally Mandelker, Exclusion and Removal Legislation, 1956 Wisc. L. Rev. 57; Note, Depression Migrants and the States, 53 Harv. L. Rev. $1031(1940 \rightarrow$ Note, Interstate Migration and Personal Liberty, 40 CoLum. L. Rev. 1032 (1940).

24. Preliminary Statement, in Brief for Appellant, In the Matter of the Appeal of Minnie Lee Nixon, State of New York, Department of Social Welfare (1964).

25. Matter of Anonymous, Docket No. 1146/64, New York County Court, May 12 1965. The Uniform Transfer of Dependents Act (U. C. A. 9 C, p. 218) provides that states may enter into reciprocal agreements with corresponding states regarding the interstate transportation of indigent persons and the acceptance, transfer and support of persons receiving public aid in other states. See, e.g., Virginia Code $\S 63-114$. Under § 63-244 of the Virginia Code no nonresident child may be placed in a foster home in Virginia without the consent of the Welfare Commissioner. The State Welfare Board is authorized to require any placing agency to agree to remove a child from the state at any time at the Commissioner's request, and the Commissioner may require any placing agency to post a bond not in excess of $\$ 2500$ conditioned on fulfillment of the agreement.

26. tenBroek, supra note 16, at 270-79 (1964).

27. N.Y. Social Welfare Law $\S 164$. See also $§ 131(4)$ (1964 Supp.) See generally, Mandelker, supra note 15 , at $36-42$. See also 42 U.S.C. $\S 607$, sanctioning State plans for aid to families with dependent children under which parents may be required to seek employment.

28. See N.Y. Times, July 30, 1964.

29. See Calif. Welfare \& Institutions Code $\$ 1523$ and Note, Charity versus Social Insurance in Unemployment Compensation Lawe, 73 YALE L.J. 357, 382, n. 94 (1963). See also N.Y. Social Welfare Law § 131(4) and 131(5) (b) (Supp. 1964).

30. See the Area Redevelopment Program, 75 Stat. 57 (1961), 42 U.S.C. § 2513 (Supp. V, 1963) (occupational retraining) and the Manpower Development and Training Program, 76 Stat. 25 (1962), 42 U.S.C. § 2582 (Supp. V, 1963). 
undergo retraining in a new occupation, not necessarily of his own choosing. The issues are sharpest where a proposed retraining program involves work that is foreign to a man's prior skills, requires acceptance of a lower status, demands transfer to a new locality, or presents the risk that no jobs will be available even after retraining. ${ }^{31}$

Housing. Public housing authorities have the power to select tenants, and also to oust them. ${ }^{32}$ Within the limits set by family income qualifications this power can be exercised in a way that is largely discretionary, based in part upon officials' intangible impressions from interviews and home visits. In deciding to admit initially or to terminate a lease, housing authorities are apparently free to use such criteria as whether any member of the family has a police record, keeps undesirable company, or engages in immoral conduct. ${ }^{33}$ The standards are generally vague, and there are no clearly articulated methods of proof. There may be little in the way of procedure to make certain that the authorities' information is true. Month-to-month leases maintain tenants in a state of insecurity.

Loyalty Oaths. Legislators apparently have a great urge to impose loyalty tests which neither the general public nor the legislators themselves are required to meet. For a time several states required a loyalty oath of applicants for public housing, ${ }^{34}$ and Ohio still has a loyalty oath for unemployment compensation. ${ }^{35}$ These instances might be dismissed as the irrational residue of the vindictive McCarthy years, were it not for the shocking fact that President Johnson's new poverty program contains the requirement that every recipient of aid thereunder take a loyalty oath. ${ }^{36}$

Criteria of Eligibility. Many of the forms of assistance contained in presentday social welfare programs, and particularly those under the Economic Opportunity Act, are, like public housing, available only on a selective basis. The

31. Strauss, Retraining and Unemployment Compensation: New Wine in Old Bottles (1964) (unpublished paper in Yale Law Library).

32. See N.Y. Pub. Housing Law § 156.

33. New York City Housing Authority Resolution No. 53-3-185, Article II, Section $2.01(\mathrm{~g})$ provides that tenancy in an authority project may be terminated for: "NonDesirability. The conduct or behavior of the tenant which is objectionable, or which imperils the health, safety or morals of his neighbors or the community, or is a source of danger or causes damages to the premises or to the property of the Authority or to the peaceful occupation of the other tenants, or constitutes a nuisance, or violates accepted social norms."

34. $: \rightarrow$ Reich, The New Property, 73 Yale L.J. 733, 747 n. 81 (1964).

35. Note, Charity versus Social Insurance in Unemployment Compensation Laws, 73 YALE L.J. 357, 379 n. 87 (1963).

36. Economic Opportunity Act, 78 Stat. 508, 533, 42 U.S.C. § 2701, 2966 :

"No part of any funds appropriated or otherwise made available for expenditure under authority of this chapter shall be used to make payments to any individual unless such individual has executed and filed with the Director an affidavit that he does not believe in, and is not a member of and does not support any organization that believes in or teaches, the overthrow of the United States Government by force or violence or any illegal or unconstitutional methods." 
list includes the Manpower Development and Training Program, ${ }^{37}$ Child Welfare Services, ${ }^{38}$ The Maternal and Child Health Program, ${ }^{39}$ The Crippled Children Service, ${ }^{40}$ as well as the programs of the Office of Economic Opportunity. ${ }^{41}$ The problem here is what criteria of eligibility are employed by the various agencies having the power of choice. A major difficulty is that in many cases the governing statutes supply no criteria at all, and the criteria actually employed by administrators are not easily discovered. For example, no regulations have been published in the Federal Register spelling out standards for the programs of the Economic Opportunity Act. The new federal job corps is reported to refuse automatically all youths with police records. In other areas standards may exist on paper but are not readily enforced.

Independence. Programs for the relief of poverty raise basic issues over how much independence is to be allowed the recipients. Under nonfederal general assistance programs "supervision" of beneficiaries by authorities is permitted. ${ }^{42}$ When such welfare is administered under a means test, the welfare agency may gain detailed control over the family budget. ${ }^{43} \mathrm{~A}$ specific type of supervision results from relief in kind, such as direct payment of rent under general assistance programs; this limits recipients' freedom of choice. ${ }^{44}$ Beyond the question of specific supervision lies a broader question - an issue which will become increasingly troublesome as programs to combat poverty grow. How much shall individuals be supervised from above, and how much by themselves? ${ }^{45}$ This fundamental issue furnishes a fitting place to halt the present sampling. Next it is important to consider what general legal problems are raised by these many issues.

\section{The Underlying Questions of LaW}

Although the issues discussed in the previous section are diverse in nature and fortuitous in selection, they do have in common some underlying legal questions. Broadly speaking, these involve matters of procedure, of constitutional law, and questions relating to the nature of the individual rights created by public welfare legislation.

By way of prologue, it should be noted that the interpretation of the applicable welfare statutes provides a series of additional important legal questions.

37. 78 Stat. 23, 42 U.S.C. \& 2571 (1964).

38. 78 Stat. 182, 42 U.S.C. $\S 721$ (1964).

39. 77 Stat. 273, 42 U.S.C. \& 701 (Supp. V 1963).

40. 77 Stat. 273, 42 U.S.C. $\$ 711$ (Supp. V 1963).

41. 78 Stat. 508 (1964), 42 U.S.C.A. § 2701 (1958).

42. See N.Y. Social Welfare Code \& 134, 214, 215, 350; Schorr, Policy Issues in Fighting Poverty, 11 ChILdRen 127 (1964); Schorr, The Trend to Rx, Soctal Work, January 1962.

43. tenBroek \& Wilson, Public Assistance and Social Insurance - A Normative Approach, 1 U.C.L.A.L. REv. 237, 264-67 (1954). On the means test generally see Mandelker, supra note 15 , Ch. IV.

44. E.g., Calif. Welfare \& Institutions Code § 1552.2.

45. See Cahn \& Cahn, The War on Poverty: A Civilian Perspective, 73 Yale L.J. 1317 (1964). 
Because welfare clients seldom have legal assistance, statutory interpretations by administrators have generally gone unchallenged. But when a real challenge is made, a significant change in prevailing practice may result. Absent challenge, welfare administrators are permitted broad areas of discretion in which they make the law by administrative interpretations under the pressures of current public opinion - interpretations that may be neither consistent from one jurisdiction to another nor in accord with the original purposes of the legislature. Each statutory question is, however, a distinctive legal problem in itself ; the present discussion will be limited to the more general questions already listed.

Procedure. In the sampling of issues already given there were many instances of welfare decisions capable of having a major impact on the lives of individuals. Many of these decisions are made in a manner that is lacking in basic safeguards. ${ }^{46}$ In the case of a decision removing a family from public housing, or a decision denying aid to families with dependent children, generally the matter is finally determined at some level within the appropriate agency, after investigation by the agency, and with comparatively informal procedures, if any, available to the persons affected. In the welfare area procedures often exist on paper, but are not pursued in practice. This contrasts sharply with what happens in agencies dealing with business regulation, where lawyers have made paper procedures a practical reality.

In the past thirty years a large body of experience and law has grown up with respect to the procedures of government agencies which undertake regulation of economic affairs, or dispensation of benefits such as airline routes or television licenses. In a general way, the standards which have developed are as follows. (1) The rules which are to furnish the standard of decision should be clearly formulated in advance of any action; (2) the rules should be available to the public; ( 3 ) every action should begin with actual notice of the proposed action and a full statement of the basis for it; (4) the relevant facts should be determined in a proceeding at which the person or company affected can know the evidence and have an opportunity to rebut it; factual findings should not be based on hearsay or secret evidence known only to the agency; (5) the person or company should have the right to be represented by counsel; (6) there should be a distinct separation between those officials who investigate and initiate action and those who find the facts and make the decision; the latter officials should be subject to different authority than the former and free of any of the atmosphere in which the action was begun; (7) the decision, once made, should be accompanied by findings and reasons; (8) there should be opportunity for review of the decision within the agency, and, ultimately, in the courts. ${ }^{47}$

46. See generally Mandelker, Judicial Review in General Assistance, $6 \mathrm{~J}$. of Pub. L. 100 (1957). Some of the most recent legislation on poverty has provisions for "finality" of determinations designed to preclude challenge and review. 75 Stat. 59 (1961), 42 U.S.C. § 2514(e) (1958); 76 Stat. 26 (1962), 42 U.S.C. § 2583 (g) (1958).

47. A fairly complete administrative procedure is found in New York City Housing Authority Resolution No. 53, 3-185. Article III of the Resolution sets up a Continued 
These procedures, however cumbersome they may seem, have come to represent a fundamental standard of fairness in administrative process. They may be exaggerated and misused until they produce inordinate delay and expense, but they represent effective checks on the characteristic evils of proceedings in any large public or private organization: closed doors, Kafka-like uncertainty, difficulty in locating responsibility, and rigid adherence to a particular point of view. They are fundamental safeguards for those who must deal with government.

In a society where a significant portion of the population is dependent on social welfare, decisions about eligibility for benefits are among the most important that a government can make. By one set of values the granting of a license to broadcast over a television channel, or to build a hydroelectric project on a river, might seem of more far-reaching significance. But in a society that considers the individual as its basic unit a decision affecting the life of a person or a family should not be taken by means that would be unfair for a television station or power company. Indeed, full adjudicatory procedures are far more appropriate in welfare cases than in most of the areas of administrative procedure. In the licensing of television or hydroelectric dams, policy-making and planning are so mixed with fact-finding as to severely limit the possibility of reaching "objective" decisions. Welfare cases rest on comparatively objective statutory criteria, are less subject to ad hoc policy-making, and demand high standards of fairness and equitable treatment for large numbers of individuals. At a minimum, there should be notice to beneficiaries of regulations and proposed adverse action, and fact finding should be carried on in a scrupulous fashion. There is much to be said for a genuine separation of the functions of investigator and judge, so that welfare workers are not put in the psychologically impossible position of having to evaluate their own actions, or those of their colleagues. And a clear statement of reasons, plus some form of review, would give a beneficiary one more opportunity to argue his side of the case. Procedures can develop gradually and pragmatically, but as welfare grows in importance in our society, it will be necessary to give increasing attention to the procedures by which welfare rights are granted or refused. Here the experience of lawyers can be of great assistance; whatever the outcome of particular decisions, adequate procedure gives a sense of fairness that is vital to community acceptance of a welfare program.

Constitutional Questions. The welfare issues discussed earlier present a number of important constitutional questions. Some of these, like the previously mentioned questions of statutory interpretation, relate to only one specific issue. Midnight searches appear to violate the Fourth Amendment. Settlement and removal statutes seem an invasion of liberty to travel and to choose one's place of abode. Relatives' responsibility laws may present issues of due process

Occupancy Board consisting of three Authority Officials empowered to hold hearings to review findings of ineligibility for continued occupancy. See also the provision for departmental appeal in the case of denial of assistance, N.Y. Social Welfare Law, $\S 139$ (a), 353. 
in imposing financial responsibility without adequate basis. But aside from these individual questions at least two problems cut across the welfare field. They involve personal liberty and equal protection of the laws.

(a) Personal Liberty. The most difficult and challenging constitutional question presented by welfare programs relates to invasions of personal liberty and privacy. "Liberty" is protected in the Fifth and Fourteenth Amendments, but nowhere defined. For many years it was used as a protection against various forms of economic and business regulation; this view is now largely discredited. But if liberty has any remaining meaning in the constitutional sense, it must at least cover the management of personal and family affairs - the sort of things that are, to the average person, nobody else's business, certainly not government's. ${ }^{48}$ Hence undue interference with the private lives of welfare beneficiaries may present serious constitutional issues.

Closely related to liberty is the concept of privacy. Privacy is not protected by any specific provision of the Constitution. But many sections of the Bill of Rights involve aspects of a right to privacy, centering on home and family. This right was expressly affirmed by the Supreme Court in the recent case of Griswold v. Connecticut, holding unconstitutional a state statute barring the use of contraceptive devices. ${ }^{49}$ Although this is a major forward step, the law has not yet developed a constitutional theory of privacy fully adequate to the present-day interdependent world. The rise of the welfare state would seem to demand that this development be delayed no longer.

(b) Equal Protection. Another developing constitutional problem is the degree to which it is valid to impose different standards of behavior upon people because they happen to receive some form of public assistance. The constitutional concept of equal protection has never been that everyone should be treated exactly the same; women may be treated differently from men, children from adults, and so forth; the guiding principle is that classifications must be reasonable. But the status of being a welfare beneficiary does not necessarily justify all of the differential forms of treatment which now exist under the law. Why should recipients of aid under the poverty program be required to take a special loyalty oath? Why should the relatives of indigent people have a greater financial responsibility than is applicable generally? As noted above, the Supreme Court of California has ruled that it violates equal protection to

48. See Griswold v. Connecticut, 33 U.S.L. WeEk 4587 (1965); see also Harlan, J., dissenting in Poe v. Ullman, 367 U.S. 497 (1961), 522, 543 :

"This 'liberty' is not a series of isolated points pricked out in terms of the taking of property; the freedom of speech, press and religion; the right to keep and bear arms; the freedom from unreasonable searches and seizures; and so on. It is a rational continuum which, broadly speaking, includes a freedom from all substantial arbitrary impositions and purposeless restraints .... and which also recognizes, what a reasonable and sensitive judgment must, that certain interests require particularly careful scrutiny of the state needs asserted to justify their abridgment."

49. 33 U.S.L. WeEk 4587 (1965). See Brief for Appellants, pp. 79-90, Griswold v. Connecticut, No. 496, U.S. Supreme Court, Oct. Term, 1964. 
make children responsible for the care of aged parents in mental institutions..$^{50}$ Again, why should welfare recipients have less freedom to take up residence in any part of the country? The test of each discrimination is that it be reasonably related to a proper object of legislative policy. And if a discrimination has come into being by administrative practice, without a basis in legislation, it should be open to much more severe questioning by the courts.

Entitlement. Beyond the procedural and constitutional problems already considered lies a further legal problem that embraces large issues of public policy. This is the question of entitlement. ${ }^{51}$

Society today is built around entitlement. The automobile dealer has his franchise, the doctor and lawyer their professional licenses, the worker his union membership, contract, and pension rights, the executive his contract and stock options; all are devices to aid security and independence. Many of the most important of these entitlements now flow from government: subsidies to farmers and businessmen, routes for airlines and channels for television stations; long term contracts for defense, space, and education; social security pensions for individuals. Such sources of security, whether private or public, are no longer regarded as luxuries or gratuities; to the recipients they are essentials, fully deserved, and in no sense a form of charity. It is only the poor whose entitlements, although recognized by public policy, have not been effectively enforced.

Perhaps at one time we could have justified this discrimination by arguing that the poor are to blame for their poverty. But today we see poverty as the consequence of large impersonal forces in a complex industrial society - forces like automation, lack of jobs and changing technologies that are beyond the control of individuals. It is closer to the truth to say that the poor are affirmative contributors to today's society, for we are so organized as virtually to compel this sacrifice by a segment of the population. Since the enactment of the Social Security Act, we have recognized that they have a right - not a mere privilege - to a minimal share in the commonwealth.

Even were this not so, the experience of thirty years has shown how much danger there is to society as a whole when any group in the population lacks entitlements and hence chronically suffers from insecurity and dependence. These same years have also shown how dangerous it is to permit government to have widespread discretionary powers over business or individuals; how

50. It is established in this state that the mere presence of wealth or lack thereof in an individual citizen cannot be the basis for valid class discrimination ....

Section 6650 by its terms imposes absolute liability upon, and does not even purport to vest in, the servient relatives any right of control over, or to recoup from, the assets of the patient. A statute obviously violates the equal protection clause if it selects one particular class of persons for a species of taxation and no rational basis supports such classification. ... Such a concept for the state's taking of a free man's property manifestly denies him equal protection of the law.

Department of Mental Hygiene v. Kirchner, 60 C.2d 716, 721-23; 388 P.2d 720, 723-24 (1964).

51. See generally tenBroek and Wilson, Public Assistance and Social Insurance A Normative Evaluation, 1 U.C.L.A.L. REv. 237 (1954). 
abuses and oppressions grow, and how the very structure of bureaucracy causes a constant reaching out for new power.

The idea of entitlement is simply that when individuals have insufficient resources to live under conditions of health and decency, society has obligations to provide support, and the individual is entitled to that support as of right. To the greatest degree possible, public welfare should rest upon a comprehensive concept of actual need spelled out in objectively defined eligibility that assures a maximum degree of security and independence. The concept of equal treatment also inheres in entitlement, and argues against basing eligibility on special statuses, such as maternity.

The evils of any public welfare system consist, to a large degree, in subjecting large numbers of people to bureaucratic discretion, in making their source of livelihood insecure by uncertain or changeable standards of eligibility, and in keeping their benefits constantly subject to the visitorial powers of the state, so that there is an excess of supervision and a lack of sufficient independence of action. The concept of entitlement attempts to meet these evils. It means objective eligibility safeguards against revocation or loss of benefits, and it means that the individual's rights, whatever they may be, should be known to him and enforceable through law. Thus entitlement is a problem for lawyers, for while the policy of entitlement is one developed by philosophers of welfare, effectuating it (particularly when the ideal must be approached pragmatically) is within the professional competence of lawyers alone.

\section{Conclusion}

The field of social welfare has developed for thirty years with relatively little attention to the protection or clarification of the legal rights of beneficiaries, especially in programs operating with a large degree of discretion. Where other fields have seen the steady growth of rights through the processes of litigation, rights that might have been developed out of existing welfare statutes have atrophied from disuse. In point of fact, the legal profession does not even know enough about agency practices in the welfare field to be able to identify possible denials of rights. There has been no systematic effort to find out what statutes, rules, administrative regulations or institutional practices may now be causing unnecessary or unjustified injury to beneficiaries or giving rise to discrimination against some of them. The sampling of problems given above was uncovered largely by fortuity; it is impossible to tell what might be revealed by a systematic search. The clients of welfare themselves are rarely in a position to know whether they are being wrongly treated.

We need a radically new approach to the field of social welfare. Today the nation's poor stand as far from the enjoyment of basic rights as did the Negro at the beginning of the Civil Rights movement. As in the case of the Negro, the avenue of reform must be through law. In a society that is highly organized, institutional and bureaucratic, law is the essential means by which individuals are protected; law alone can ensure the fairness and lack of oppression that is 
essential to individual independence. ${ }^{52}$ The field of social welfare has grown up with virtually no participation by lawyers at the level where individual rights are at stake. Lawyers are desperately needed now. ${ }^{53}$

We need organized legal research to examine statutes, regulations, manuals and practices to determine where changes are needed. We need institutions capable of financing both legal research and test cases to determine the extent of rights in given areas. And we need lawyers to represent individual clients who cannot pay for help or secure that help from any existing organizations; it is only through individual cases that the law comes into being and keeps on growing.

The condition of the field of social welfare is an indictment of the present day legal profession. Lawyers have simply not been available when help was needed. There are virtually no organized sources of legal aid to assist persons with welfare problems, law schools have no courses designed to prepare lawyers for such service, and the need for lawyers is rarely recognized by the agencies themselves or the individuals concerned. Today, as law increasingly becomes our central instrument of social policy, we can no longer afford this form of neglect.

By the same token, decisions concerning human rights are too important to be left to public welfare workers and public administration officials without the aid of law. Law is needed to help them to see issues clearly, to guide them, and to strengthen their good intentions. In a constructive alliance of law and social welfare there lies hope for a fundamental change in the status of the disadvantaged of our society - a bill of rights for the disinherited.

$5 \rightarrow$ Jones, The Rule of Law and the Welfare State, 58 Colum. L. Rev. 143 (1958).

53. See The Availability of Counsel and Group Legal Services: A Symposium, 12 U.C.L.A.L. Rev. 279 (1965), especially Sparer, The Role of the Welfare Client's Lawyer, 12 U.C.L.A.L. Rev. 361 (1965) ; Carlin \& Howard, Legal Representation and Class Justice, 12 U.C.L.A.L. Rev. 381 (1965). 